\title{
Optical Proximity Correction using an Optimization Method after Layout Design
}

\author{
Tetsuaki Matsunawa Student Member (University of Tsukuba, t-matsunawa@aist.go.jp) \\ Hirokazu Nosato Non-member (MIRAI-AIST, h.nosato@aist.go.jp) \\ Hidenori Sakanashi Non-member (MIRAI-AIST, h.sakanashi@aist.go.jp) \\ Masahiro Murakawa Member (MIRAI-AIST, m.murakawa@aist.go.jp) \\ Nobuharu Murata Non-member (MIRAI-AIST, nobu-murata@aist.go.jp) \\ Tsuneo Terasawa Non-member (MIRAI-ASET, t-terasawa@mirai.aist.go.jp) \\ Toshihiko Tanaka Member (MIRAI-ASET, tanaka.toshihiko@aist.go.jp) \\ Osamu Suga Non-member (Selete, suga@selete.co.jp) \\ Tetsuya Higuchi Non-member (University of Tsukuba, MIRAI-AIST, t-higuchi@aist.go.jp)
}

Keywords: lithography, optical proximity correction, genetic algorithm, optimization

Recently the increases in the calculation loads for optical proximity correction (OPC) are leading to increases in mask costs, which is becoming a problem for semiconductor manufacturing. OPC is a method of canceling out optical proximity effects (OPE) by providing an inversely-distorted feature shape on a mask pattern. OPC involves huge costs for the following reasons: (1) the execution of accurate optical simulations to calculate the OPE over the full-chip area (full-chip OPC), and (2) the need to apply OPC to the entire chip, even in cases requiring only partial circuit correction.

In order to overcome these problems, we propose an approach to OPC using an adjustable OPCed cell and genetic algorithms (GA) to achieve optimal OPC feature generation for the full-chip area at fast processing speeds. GA is an efficient optimization technique based on population genetics. An example of the adjustable OPCed cell is shown in Fig.1. Panel (a) is a standard cell consisting of the design patterns only. Panel (b) is the adjustable OPCed cell which consists of two parts. The first part is the "fixed area", which includes OPC feature data from a conventional OPC technique. The second part is the "adjustable area", which is located in the peripheral regions of the cell and includes adjustable OPC variables. As the values of these variables are greatly influenced by neighboring cell patterns, the variables are quickly optimized by the GA after cell layout.

In this paper, a verification experiment was conducted with the test patterns of a small-scale LSI. The experimental results show that the GA optimization realized the generation of OPC features with less than $3 \%$ error, as defined by the International Technology Roadmap for Semiconductors (ITRS). Moreover, the results show that, even in cases re- quiring only partial circuit correction after layout design, the OPE can be corrected by local correction alone.

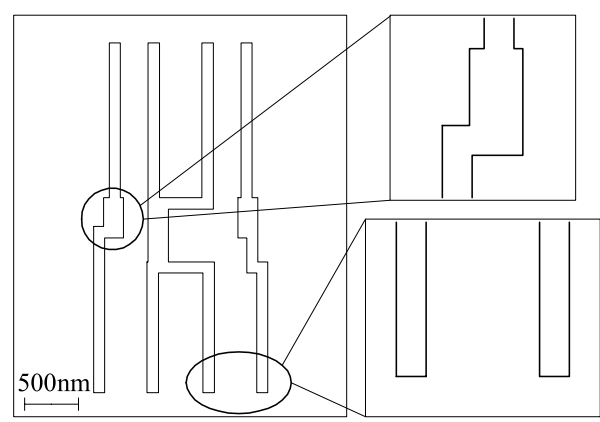

(a) Standard cell

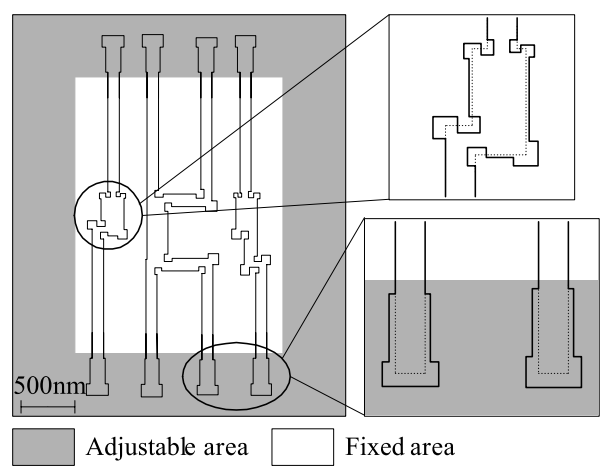

(b) Adjustable OPCed cell

Fig. 1. Adjustable OPCed cell 


\section{レイアウト設計後の最適化による光近接効果補正技術の提案}

$\begin{array}{llllll}\text { 学生員 } & \text { 松縄 } & \text { 哲明* } & \text { 非会員 } & \text { 野里 } & \text { 博和** } \\ \text { 非会員 } & \text { 坂無 } & \text { 英徳** } & \text { 正 員 } & \text { 村川 } & \text { 正宏** } \\ \text { 非会員 } & \text { 村田 } & \text { 信治** } & \text { 非会員 } & \text { 寺澤 } & \text { 恒男*** } \\ \text { 正員 田中 } & \text { 稔彦*** } & \text { 非会員 } & \text { 須賀 } & \text { 治**** } \\ \text { 非会員 樋口 } & \text { 哲也*,** } & & & \end{array}$

\section{Optical Proximity Correction using an Optimization Method after Layout Design}

Tetsuaki Matsunawa*, Student Member, Hirokazu Nosato**, Non-member, Hidenori Sakanashi**, Non-member,

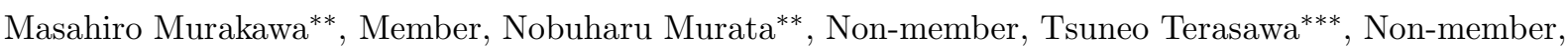
Toshihiko Tanaka**, Member, Osamu Suga***, Non-member, Tetsuya Higuchi, ${ }^{* * *}$, Non-member

This paper proposes an optical proximity correction (OPC) using an Adjustable OPCed cell and genetic algorithms (GA) to achieve optimal OPC feature generation for the full-chip area at fast processing speeds. GA is an efficient optimization technique based on population genetics. In this approach, an Adjustable OPCed cell consists of two parts. The first part is the "fixed area", which includes OPC feature data from a conventional OPC technique. The second part is the "adjustable area", which is located in the peripheral regions of the cell and includes adjustable OPC variables. As the values of these variables are greatly influenced by neighboring cell patterns, the variables are quickly optimized by the GA after cell layout. The effectiveness of this approach, in terms of reduced times for accurate simulations and repeated modification of OPCed features, is demonstrated through computational experiments.

キーワード : リソグラフィ, 光近接効果補正, 遺伝的アルゴリズム, 最適化

Keywords: lithography, optical proximity correction, genetic algorithm, optimization

\section{1. はじめに}

半導体産業では, LSI の集積密度の増加に伴い, 光リソ グラフィの解像度を向上させるための技術が求められてき た。代表例として，位相シフトマスク (1) や変形照明 (2) な

* 筑波大学大学院 システム情報工学研究科

T 305-8577 茨城県つくば市天王台 1-1-1

University of Tsukuba

1-1-1 Tenoudai, Tsukuba, Ibaraki 305-8577

**半導体 MIRAI プロジェクト 産業技術総合研究所 次世代半導体

研究センター $=305-8568$ 茨城県つくば市梅園 1-1-1

MIRAI-ASRC, AIST

1-1-1 Umezono, Tsukuba, Ibaraki 305-8568

*** 半導体 MIRAI プロジェクト 技術研究組合 超先端電子技術開発

機構 ₹ 305-8569 茨城県つくば市小野川 16-1

MIRAI-ASET

SCR Bldg, 16-1 Onogawa, Tsukuba, Ibaraki 305-8569

**** (株) 半導体先端テクノロジーズ

干 305-8569 茨城県つくば市小野川 16-1

Semiconductor Leading Edge Technologies, Inc.

16-1 Onogawa, Tsukuba, Ibaraki 305-8569
どの超解像技術が挙げられる。しかしながら，現在，これ らの技術だけでは，ウェハに転写するパターンの忠実性を 維持することが難しくなっている。なぜならば，微細化が 進むにつれて光近接効果 (OPE : Optical Proximity Effect）が顕在化するからである。これは, ウェハ上に到達す る光が減少することによって，パターンの忠実性が低下す る現象である。そこで, OPEを打ち消すパターンを生成す る手法である光近接効果補正 (OPC : Optical Proximity Correction) が重要となっている(3)。

従来の $\mathrm{OPC}$ では, 最小単位の回路であるセルをレイア ウトしてマスクパターンを構成した後に，マスク全面に対 して補正図形生成の計算 (チップ全面 OPC) を行っていた。 しかし, 現在, 半導体デバイスの微細化に伴う補正計算の複 雑化のために, OPC に要する計算負荷 (時間・マスクデー 夕量) が増加している。これが，マスクコストを引き上げる 深刻な要因の 1 つとなっている。さらに, チップ全面 $\mathrm{OPC}$ は, レイアウト後に回路の一部を修正した場合, 再度チップ 全面計算が必要とされるため，レイアウト後に複数回の修 
正が必要とされる LSI 製造において, TAT（Turn Around Time）の増加など, 深刻な問題の一因となっている。

この問題を解決するために, cell-wise OPC と呼ばれる OPC 手法が提案されている。cell-wise OPC は，レイアウ 卜前にセル毎の $\mathrm{OPC}$ 計算を行うことでチップ全面 OPC を 不要とし, OPCの計算時間を低減した手法である ${ }^{(4)}$ 。し かしながら, セルレイアウト後の OPEの影響について十 分な補正精度が確保されておらず，複雑な計算を必要とす る等の問題が残されている。

そこで，これらの問題を解決するために，我々は，以 前, 新たな OPC 手法として Post-placement optimization method を提案した ${ }^{(5)}$ 。この提案では, 次の 2 つの基本概念 を示し，シミュレーション実験によりその有効性を示した。

(1) Adjustable OPCed cell：これは, 予め OPCが適用 されたセルであり, OPC 罒形の調整が可能な Adjustable 領域と, OPC 図形が固定された Fixed 領域を持つ。

(2) セルレイアウト後の OPC 図形の最適化: Adjustable OPCed cell によりレイアウトを行った後, Adjustable 領 域の OPC 図形を最適化により調整する。

この Post-placement optimization methodには, 次の 2 つの利点がある。(1) Adjustable OPCed cellにより Fixed 領域の OPC 計算を不要にできるため，チップ全面 OPCに 対して計算領域を削減することができる。（2）セルレイア ウト後の最適化によりレイアウトによって発生する OPEを 打ち消すことが出来るため, 高精度な OPC が実現できる。

しかし，上記の提案では, Adjustable 領域の明確な定義 を行っておらず，またレイアウト後の回路修正による OPE を部分的な計算だけで補正できる利点は検証していなかっ た。そこで，本論文では次の 2 つを明らかにすることを目 的とする。

（1）Adjustable 領域を明確に定義することで計算領 域の削減（計算時間の短縮）について検討し，また Adjustable 領域のみの計算で高精度な OPC が実現 できることを示す。

（2）レイアウト後の回路修正により発生する OPEを， チップ全面 OPC を行うことなく局所的な計算で補 正可能であることを示す。

以下， 2 章では従来の $\mathrm{OPC}$ 手法の問題点について説明し, 3 章でそれらの問題点を解決するための提案手法について 述べる。4 章では，実験結果から，提案する Adjustable 領 域の効果を示し，またレイアウト後に回路修正を行っても 局所的な計算で OPE が補正できることを示す。 5 章で今 後の課題について議論し, 結論を述べる。

\section{2. 光近接効果補正とその問題点}

光リソグラフィでは，マスクパターンによって回折された 光をウェハ上に集光させることで露光パターンを形成する。 しかし, 半導体デバイスの微細化に伴い, 露光パターンの 最小ピッチの半分 (hp : half pitch) が露光波長以下になる と, マスクパターンによって回折された光のうち, ウェハ上
に到達できる回折光の次数が低下する。これによって露光 パターンの忠実性が低下する現象を, 光近接効果 (OPE) と呼ぶ。OPE は, 露光波長 $248 \mathrm{~nm}$ で hp $350 \mathrm{~nm}$ のマス クパターンを転写する $350 \mathrm{~nm}$ 世代の光リソグラフィでは それほど問題視されていなかったが, 現在主流となってい る 90nm 世代 (hp 90nm, 露光波長 $193 \mathrm{~nm})$ の光リソグラ フィでは深刻な問題となっている。光近接効果補正 (OPC) は, OPE を事前に予測し, マスクパターンの寸法や形状 を補正することでマスクパターンのウェハへの転写精度を 向上させる技術である。OPC の補正手法は, 主にルール ベース $\mathrm{OPC}^{(7)}$ とモデルベース $\mathrm{OPC}^{(8)}$ に大別することが できる。

\section{$\langle 2 \cdot 1\rangle$ ルールベース OPC とモデルベース OPC}

ルールベース OPC は, 隣接パターンの距離や寸法に応 じて補正図形の形状や寸法を定めるルールテーブルを作製 し，これに従ってマスクパターンを補正する。この方法に は，計算速度が速く，補正後のマスクデー夕量があまり大 きくならないという利点がある。しかし, 補正精度を向上 させるためには複雑なルールが必要となるため，ルールを 作製する作業負荷が増大する。さらに，半導体デバイスの 微細化が進むと十分な補正精度を得るのが難しくなる。こ れは, OPEの影響範囲が, 隣接するパターン間の最小距離 を越えるために補正精度が急激に悪化することによる。そ のため, hp $130 \mathrm{~nm}$ 世代以降の OPCでは, ルールベース $\mathrm{OPC}$ は精度があまり必要とされない部分などに限定され 用いられている。

モデルベース OPC では, OPEによって変動する露光パ ターンの形状や寸法を光学シミュレーションにより予測し て，これを打ち消すための補正図形を作製する。この方法 は，ルールベース OPCよりも緻密な補正を行うことがで きるため, hp $130 \mathrm{~nm}$ 世代以降の $\mathrm{OPC}$ の補正精度に対応 可能である。しかしながら, モデルベース OPCでは, マス クを構成する全てのパターンに対して補正計算を行う（チッ プ全面 OPC）ために, 膨大な計算負荷（時間，マスクデー 夕量）がかかるという問題点がある。この計算負荷は, 半 導体デバイスの微細化とともに増加しており, マスクコス 卜を引き上げる深刻な要因の 1 つとなっている。加えて, レイアウト後に回路修正を行った場合は, 再度チップ全面 計算が必要とされることから, 計算時間が増大し, マスク 製造の TAT 増加などの一因となっている。これらの問題 点は, 半導体産業において, デバイスの微細化を妨げる深 刻な問題として認識されている(3)。

〈2・2〉 cell-wise OPC チップ全面のモデルベース OPCの問題点を解決するための手段として, cell-wise OPC が提案されている。cell-wise OPC の特徵は，レイアウト 設計の前段階でセル毎に OPC を適用することでチップ全 面 OPC を不要とし, OPC の計算時間とマスクデータ量を 削減することである。

代表的な cell-wise OPC では，セルライブラリ設計段階 で使用頻度の高い標準的なセルに対して OPC を適用してい 
る(4)。しかしながら, 次の 2 つの理由から, cell-wise OPC では高精度な補正が困難と考えられる。（1）OPEは隣接セ ルの影響を受けるため，最適な OPC 図形はセルの隣接環 境によって大きく変化する。加えて, セルの隣接環境はレ イアウトの後まで決定することができない。（2）各セルの 周辺部に特定のパターンを定義することで，セルがレイア ウトされる環境を想定している。そのため, 想定外のセル がレイアウトされると OPEを打ち消すことが困難になる。

一方, 補正精度を確保するために, 複数の OPC 罒形を 用意することで様々な隣接環境に対応する手法も提案され ている ${ }^{(9)}$ 。しかしながら, 複雑な手続きが必要であること や，レイアウト直後に一度はチップ全面 OPCが必要とさ れるなどの問題が残されている。

\section{3. 提案手法}

本章では，上述した問題点を解決するためのアプローチ として, Post-placement optimization method ${ }^{(5)}$ を基に 提案する $\mathrm{OPC}$ 手法について述べる。〈3・1〉節で本手法の概 要を説明し，〈3・2〉節で Adjustable OPCed cell の構成を 述べる。〈3・3〉節では Adjustable 領域の定義について説明 し，〈3・4〉節でレイアウト後の回路修正に対応した遺伝的ア ルゴリズムを用いた OPC 図形の最適化について述べる。

$\langle\mathbf{3 \cdot 1}\rangle$ 提案手法の概要 本手法は, チップ全面 $\mathrm{OPC}$ を必要とせず高精度な補正を目的とする OPC であり, 次 の 2 つの基本アイデアに基づいている。

(1) Adjustable OPCed cell：これは, 予め OPC が適 用されており, Adjustable 領域と Fixed 領域を持つセルで ある。Adjustable 領域は, セルの周辺部に位置し, OPC 罒形の調整計算を可能にする領域である。これにより，隣 接セルの影響による OPE を補正することができる。一方， Fixed 領域は隣接セルによる OPEの影響が少ないセルの中 心部に位置し, OPC 図形が固定された領域である。Fixed 領域では, OPC 困形の調整計算を不要にすることができ る。図 1 の（a）に，従来手法と比較したレイアウト後の セルの計算領域を示す。網掛部が OPC の計算領域，白色 部が計算不要の領域を示している。本手法を用いることで, OPC の計算領域の大幅な削減が期待できる。

(2) 七ルレイアウト後の OPC 図形の最適化：この最適 化では, Adjustable OPCed cell によりレイアウトを行っ た後, Adjustable 領域の OPC 図形を, 隣接セルからの OPE を打ち消すように調整する。これにより, セルの隣接 環境が変わっても, 隣接する Adjustable 領域のみの計算 で, cell-wise OPC では困難であった高精度な補正が可能 となる。さらに, 図 1 の（b）に示すように, レイアウト 後に回路修正を行っても，チップ全面 OPC を行うことな く局所的な計算で OPEの補正が可能となる。

（1）と（2）の基本アイデアにより，少ない計算時間で高 精度な補正が可能な OPC が期待される。

〈3・2〉 Adjustable OPCed cell の構成 Adjustable OPCed cell は, セルを定義する設計パターンと, 上述し

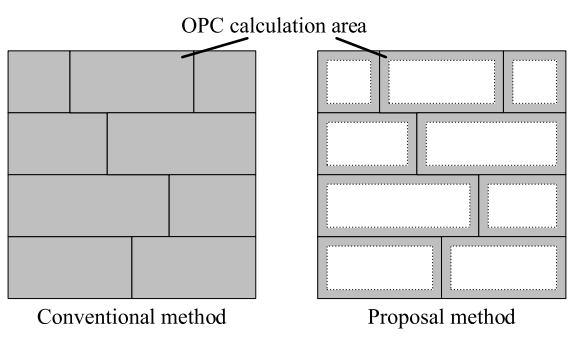

(a) Reduction of calculation area

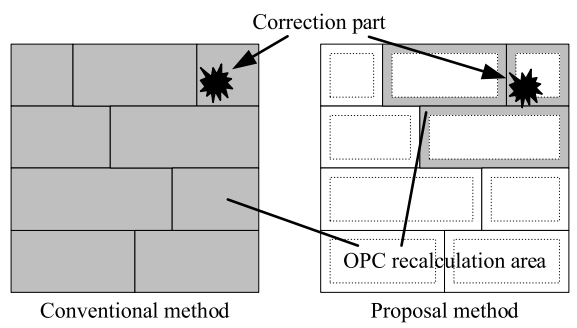

(b) Local correction

困 1 本手法の特徵

Fig. 1. Feature of proposal method.

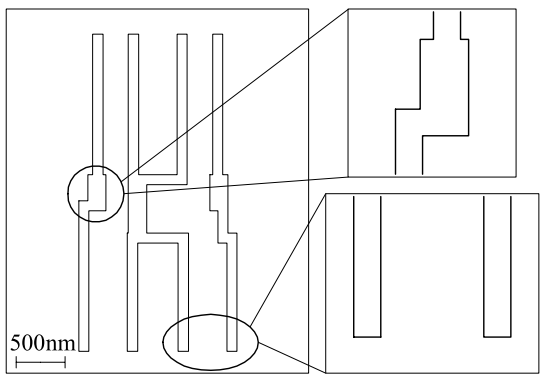

(a) Standard cell

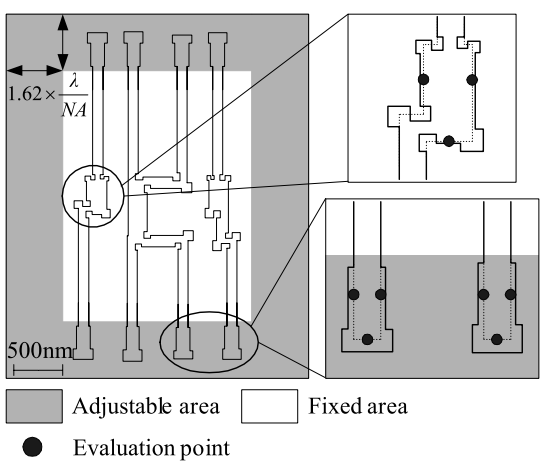

(b) Adjustable OPCed cell

図 2 Adjustable OPCed cell の例

Fig. 2. Adjustable OPCed cell.

た Adjustable 領域と Fixed 領域, 最適化で用いる評価点 で構成される。図 2 に通常のセルと Adjustable OPCed cell の例を示す。(a) は通常のセルで, これは設計パターン のみで構成されている。一方, (b) は Adjustable OPCed cell である。Adjustable OPCed cell は, (a) の設計パター ンに OPC を適用した後, セルの周辺部を Adjustable 領 域, セルの中心部を Fixed 領域と定義することによって作 製される。Adjustable 領域の OPC 図形を Adjustable 図 
形，Fixed 領域の OPC 図形を Fixed 図形と呼ぶ。(b) の 網掛部が Adjustable 領域，白色部が Fixed 領域を表す。 なお，(b) の黒点は評価点を示しており，これは，設計パ ターン上で，コンタクト部や拡散層上の配線部等，高精度 な OPC が求められる箇所に設定する。評価点では, OPC 図形の効果を検証するために，光学シミュレーションによ る投影像と設計パターンのずれの割合を誤差として測定す る。後述する最適化において, Adjustable 図形は,この誤 差が最小となるように調整される。

〈3·3〉Adjustable 領域の定義＼cjkstart本論文では，理想 光学系の回折理論をもとに, Adjustable 領域はセルの端か ら $1.62 \lambda / N A$ の範囲と定めた。この理由を次に示す。

Adjustable 領域は, 隣接セルを構成するパターンからの 回折光が重なることで起こる干渉の影響を補正するための 領域である。そこで，Adjustable 領域の範囲を決めるため に，マスクパターンを円形開口と近似した場合の回折像強 度について考える。直径が $a$ の開口を考えると，回折像の 強度 $I$ は,

$$
I(a R)=\left(2 \frac{J_{1}(a R)}{a R}\right)^{2} .
$$

で表せる $\left(R=\frac{2 \pi}{\lambda b} \rho\right)^{(10)}$ 。ただし， $J_{1}: 1$ 次の Bessel 関 数, $\lambda$ : 波長, $b$ : 開口から像面までの距離, $\rho$ : 像半径，で ある。 $a R$ と強度 $I$ の関係を図 3 に示す。これより, 最 初に $I=0$ となる半径を $\rho_{1}(a R=3.8317)$ とすれば, $\rho_{1}=0.61 \lambda / N A$ となる。また， $(I=0$ となる $) 2$ 次回 折像までの半径を $\rho_{2}(a R=7.0156), 3$ 次回折像までの 半径を $\rho_{3}(a R=10.1735)$ とすると, $\rho_{2}=1.12 \lambda / N A$, $\rho_{3}=1.62 \lambda / N A$ となる。 3 次回折像の最大強度は, 0 次 時回折像の $0.2 \%$ 以下であるため（図 3 ), 3 次回折像によ る干渉の影響は無視できるほど小さいと考えられる。した がって, 本論文では, OPCパターンの変化が周囲に与える 影響の範囲を 3 次回折像までと考え, Adjustable 領域をセ ルの端から $1.62 \lambda / N A$ と定義した。これは，実際の露光条 件における OPE と照らし合わせても妥当な範囲と言える。

この場合，セルの平均サイズを $5 \times 5 \mu \mathrm{m}^{2}$ ，チップサイズ を $81.92 \times 81.92 \mu \mathrm{m}^{2}$ と仮定すると，計算面積はチップ全 面計算と比較して約 $1 / 3$ に削減することが可能になる。リ ソグラフィシミュレーションでは，ウェハ上の 2 次元投影 像を計算するため，計算量は計算面積の 2 乗に比例する。

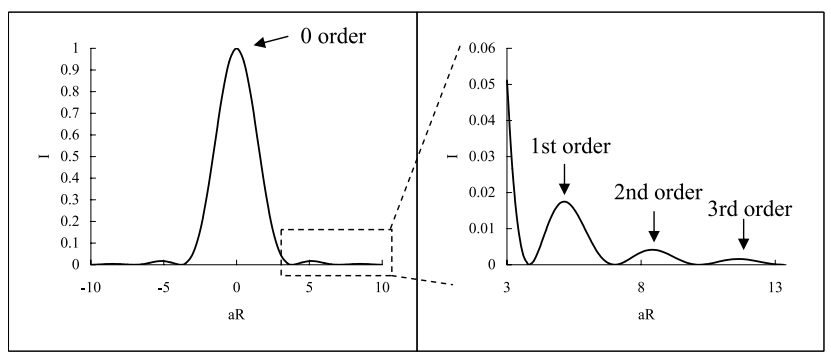

図 3 回折像強度

Fig. 3. Intensity of diffraction image.
そのため，計算面積を約 $1 / 3$ に低減できれば，計算量を約 $1 / 9$ に削減することが可能になる。

さらに，隣接セルの状態によっては，Adjustable 領域 はより小さく定義できる可能性がある。例えば，隣接セ ルのサイズが小さく，設計パターンの密度が低い場合であ る。このような場合は，回折光が少なく，干渉の影響を無視 することができるため, Adjustable 領域を $1.12 \lambda / N A(2$ 次回折像まで）で定義しても補正が可能と考えられる。こ の場合，セルの平均サイズを $5 \times 5 \mu \mathrm{m}^{2}$, チップサイズを $81.92 \times 81.92 \mu \mathrm{m}^{2}$ と仮定すると, 計算面積はチップ全面計 算と比較して約 $1 / 4$ に, 計算量は約 $1 / 16$ に削減すること が可能になる。

〈3・4〉 セルレイアウト後の OPC 図形の最適化 Adjustable OPCed cell のレイアウトを行うと, 各セルの周辺 部では，隣接セルによる OPEの影響を受けるために，各 セルの Adjustable 図形の再調整が必要になる。加えて, レ イアウトにおけるセルの組み合わせの数は膨大であるため, Adjustable 困形の調整は困難である。そのため, 本論文で は, Adjustable 図形の調整に, 確率的探索手法の 1 つで, 複数の解候補を並列的に探索することができる遺伝的アル ゴリズム (GA：Genetic Algorithm) (6)を用いた。

GA には，局所解を回避するための多様性の維持と，解 の収束性においてバランスのとれた世代交代モデルである MGG (Minimal Generation Gap) (11) モデルを用いた。 また, GA の遺伝的操作には正規乱数型突然変異 (12) を用い た。本論文で提案する GA のフローチャートを図 4 に示す。 全体の流れとしては，まず，Adjustable 図形の形状や寸法 を, 最適化手法の調整変数として扱うために染色体として コード化し (Coding)，染色体の初期集団をランダムに用 意する。その後，集団から個体を選択して (Selection)，突 然变異による遺伝的操作を行う (Mutation)。次に，光学

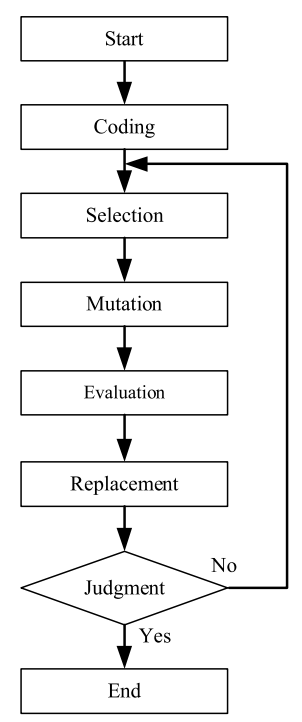

図 4 GA の調整フロー

Fig. 4. The flowchart for the optimizaiton. 
シミュレーションにより投影像を計算し，適応度を評価す る (Evaluation)。そして, 遺伝的操作によって発生した個 体を，適応度に応じて淘汰し，置換する（Replacement）。 GA による探索は，適応度がある值以上の個体を探し出す まで繰り返す。

以上の手順で，光学シミュレーションによる投影像が設 計パターンに近づくようにAdjustable 図形を調整する。以 下では, Adjustable 図形の染色体へのコード化と適応度の 計算方法について説明する。

〈3・4・1〉 コード化 コード化では, Adjustable 図形 の形状を決める変数を，調整箇所と同じ数で構成される一次 元配列で表現する。図 5 にコード化の例として, Adjustable 図形の調整箇所と，この調整箇所に対応した，最適化にお ける染色体の遺伝子配列を示す。眓のように，染色体は調 整箇所と等しい数の遺伝子から成り，それぞれの遺伝子は 調整箇所である Adjustable 図形の多角形の辺（図 5 の a, $\mathrm{b}, \mathrm{d}, \mathrm{e}, \mathrm{g}, \mathrm{h}, \mathrm{j}, \mathrm{k}$ ), あるいは多角形の線幅（図 5 の c, $\mathrm{f}, \mathrm{i}, \mathrm{l})$ を示し，実数值で表現される。

$\langle\mathbf{3 \cdot 4 \cdot 2 \rangle}$ 適応度計算 最適化で用いる適応度の計算 は, 次の手順で行う。まず, 光学シミュレータを用いて, 染 色体より定まったマスクパターンの投影像を計算する。こ の結果をもとに, 評価点において, 投影像の寸法 $P$ と設計 パターンの寸法 $O$ のずれの割合を誤差 $F$ として次式で計 算する。

$$
F_{i}=\left|O_{i}-P_{i}\right| / O_{i}
$$

ここで， $i$ は評価箇所を表す。以上のように全ての評価箇所 における誤差を計算し，その中の最大誤差 $\max \left\{F_{i}\right\}$ を用

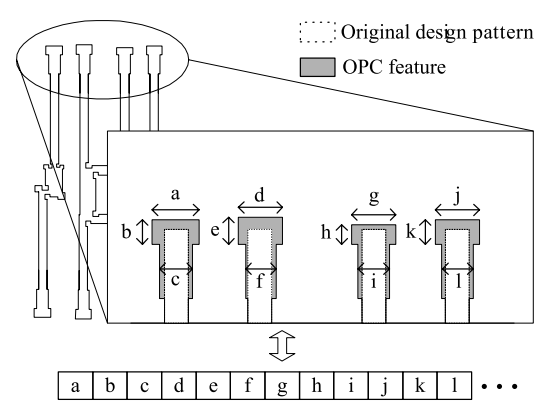

図 5 Adjustable 図形の染色体へのコード化

Fig. 5. Coding to chromosomes.

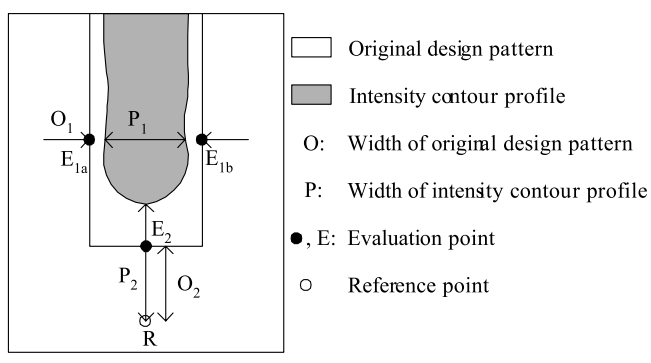

困 6 投影像の測定例

Fig. 6. Measurement of intensity contour profile.
いて，次式により適応度を計算する。

$$
\text { 適応度 }=1 / \max \left\{F_{i}\right\}
$$

適応度の值が最大となる（誤差が小さくなる）ことが, 最 適な Adjustable 図形が生成されることを意味する。

投影像の評価方法は線幅と先端部で異なるため，これを 困 6 を用いて説明する。線幅を評価する場合は，2つの評 価点 $E_{1 a}, E_{1 b}$ の間の距離を設計パターンの寸法 $O_{1}, E_{1 a}$ と $E_{1 b}$ を結ぶ線上における投影像の幅を投影像の寸法 $P_{1}$ として，(2) 式で $F_{1}$ を計算する。投影像の先端部を評価 する場合は, 設計パターンの外部で, 評価点 $E_{2}$ を含む線 分の垂線上に参照点 $R$ を設け, この点から評価点 $E_{2}$ まで の距離を設計パターンの寸法 $O_{2}$, 投影像の先端までの距 離を投影像の寸法 $P_{2}$ として, $(2)$ 式で $F_{2}$ を計算する。な お，後述するシミュレーション実験では，図 6 における $O_{2}$ が線幅 $O_{1}$ の 2 倍となるように参照点を設定した。これは, ゲート幅よりもゲート長の方が高い精度が要求されること に加え, 線幅の精度を先端部の 2 倍にとることで探索効率 が向上することを予備実験により確認したためである。

\section{4. シミュレーション実験}

本章では，提案手法の有効性を示すために，まず実験 1 において，提案した Adjustable 領域の妥当性を検証する。 次に実験 2 において, レイアウト後の回路修正により発生 する OPEを局所的な計算で補正できることを検証する。以 下，はじめに光学シミュレーションの実験条件について述 ベ，次に使用するテストパターンの作製と，これを用いた 実験について説明し，実験結果について述べる。

$\langle\mathbf{4} \cdot \mathbf{1}\rangle$ 実験条件と実験準備 光学シミュレーションに は, 部分コヒーレント結像理論 (10) をもとに作製した光学シ ミュレータを用いた。計算機の性能は, CPU：Opteron244, Memory:16GB, OS:Red Hat Linux である。光学シミュ レーションでは，現在主流となっている $90 \mathrm{~nm}$ ライブラリ の回路の光学条件として 波長 $=193 \mathrm{~nm}, N A=0.7($ $\left.k_{1}=0.32\right)$ を想定した。実験では, $130 \mathrm{~nm}$ ライブラリの回 路を用いたので, $k_{1}$ 值を等しくするために, 波長 $=193 \mathrm{~nm}$, $N A=0.48$ としてシミュレーションを行った。また，その 他の光学条件は, 輪帯照明 $(\sigma$ 外径/内径 $)=0.85 / 0.55)$, 位相シフトマスク（透過率 $6 \%$ ）と設定した。

実験の準備として, (株) 半導体理工学研究センター (STARC) が開発した $130 \mathrm{~nm}$ ライブラリを用いて, cell 1 から cell 5 の 5 つの Adjustable OPCed cell を作製し た。これは, 光学シミュレーションに用いるテストパター ンを作製するためのセルである。それぞれのセルでは, Adjustable 領域はセルの端から $1.62 \lambda / N A$ の領域, 残りを

\section{表 1 各セルの調整図形の数}

Table 1. Number of adjustment features.

\begin{tabular}{c|c|c|c|c}
\hline cell 1 & cell 2 & cell 3 & cell 4 & cell 5 \\
\hline \hline 24 & 24 & 18 & 24 & 24 \\
\hline
\end{tabular}




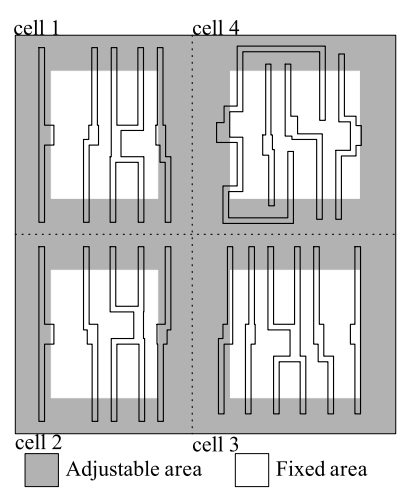

(a) Adjustable area and fixed area

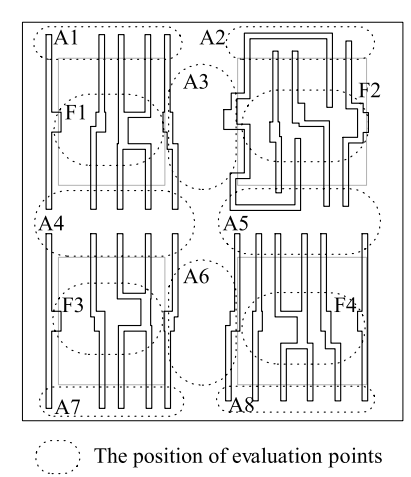

(b) Evaluation points

図 7 pattern $\mathrm{A}$

Fig. 7. pattern A.

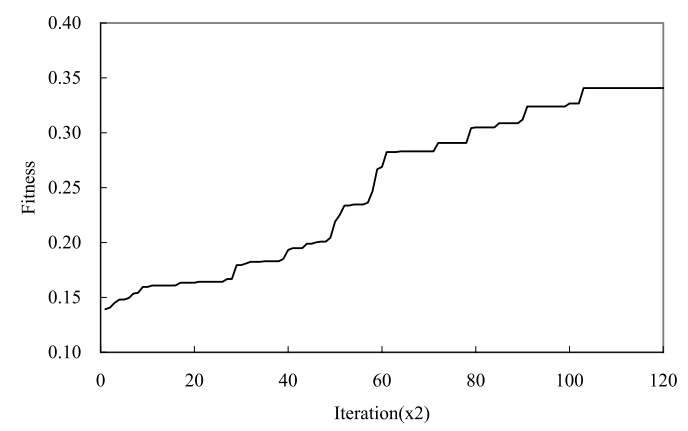

図 8 補正実験の収束の様子 (5 試行平均)

Fig. 8. Fitness versus iterations for the experiments.

Fixed 領域に設定した。各セルの調整図形の数を表 1 に示 す。また，評価点は，ウェハ上の投影像の寸法を確保するた めに, Adjustable 領域内では設計パターンの先端に, Fixed 領域内では設計パターンの中心部に設定した。なお，各セ ルの OPC の補正精度は ITRS（International Technology Roadmap for Semiconductors) で定められている $3 \%^{(13)}$ とした。

$\langle\mathbf{4} \cdot \mathbf{2}\rangle$ 実 $\quad$ 験 1 セル単体の OPC の補正精度が $3 \%$ であっても，レイアウトを行うと，隣接セルによる OPE の影響を受けるために最適な OPC 図形は变化する。そこ で，我々は，レイアウト後に OPC 図形の調整を可能とす るAdjustable 領域を定義した。本実験では，隣接セルによ る OPEの影響範囲を検証し，これを補正することで，定 義した Adjustable 領域の妥当性を検証する。以下，レイ アウト設計によって発生する OPE の影響範囲の検証結果 と，ここで発生した OPEの補正実験について述べる。

\section{$\langle\mathbf{4} \cdot \mathbf{2} \cdot \mathbf{1}\rangle \quad \mathrm{OPE}$ の影響範囲の検証＼cjkstart隣接セルによる} OPE の影響範囲を検証するために, cell 1 から cell 4 の Adjustable OPCed cell をレイアウトし，テストパターン （pattern A）を作製した。図 7 の（a）に pattern Aの Adjustable 領域と Fixed 領域を，(b)に評価領域を示す。こ こで, 評価領域は複数の評価点が含まれる領域を表す。(b) の $\mathrm{A} 1 \sim \mathrm{A} 8$ は Adjustable 領域内の評価領域, F1〜F4 は

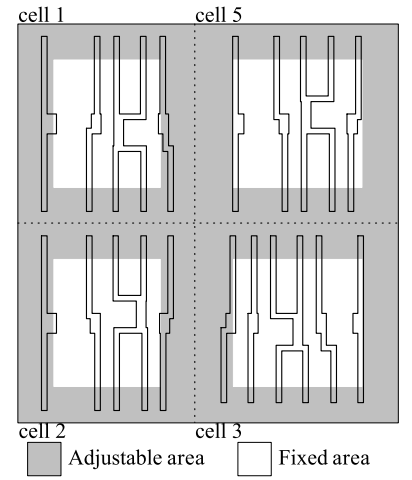

(a) Adjustable area and fixed area

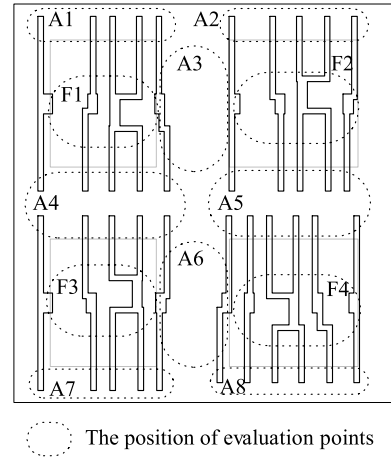

(b) Evaluation points
図 9 pattern $\mathrm{B}$

Fig. 9. pattern B.

Fixed 領域内の評価領域を示す。なお，pattern A には 107 箇所に評価点があり, それぞれの評価点は, 露光パターン の線幅あるいは露光パターン先端の寸法を評価する箇所に 設定した。表 2 に, 各評価領域における線幅変動の最大值 と最小值拧よび平均值を示す。なお，線幅変動は, 露光パ ターンが設計パターン幅に対してどの程度変動したかを誤 差で表したものとする。表から, Adjustable 領域では最大 8.4\%（領域 A4）の誤差が生じているのに対して, Fixed 領 域では誤差は $3 \%$ 以内に収まっていることが確認できる。

Adjustable 領域の中で誤差が $3 \%$ を超えるのは A4 と A 5 の領域であることから，A1，A2，A7，A8 など周囲にセル が配置されていない場合は OPEの影響は受けないことが わかる。また，A3，A6 領域においても誤差が $3 \%$ 以内に 収まっているのは, この領域では, パ夕ーン間の距離が離 れていることにより OPEの影響を受けないためと考えら れる。

$\langle\mathbf{4} \cdot \mathbf{2} \cdot \mathbf{2}\rangle$ 提案手法を用いた OPE の補正実験 $\mathrm{A} 4$, A5 領域の線幅変動を，提案手法により補正した。目標とする 精度は設計パターンの $3 \%$ 以内 (適応度 0.33 以上), 染色体 の長さは $45, \mathrm{GA}$ の初期個体は 90 個, 突然変異 $(\sigma N(0,1))$ の $\sigma$ は $3.0(\mathrm{~nm})$ として調整を行った。ここで, $N(0,1)$ は平均 0 , 分散 1 の正規乱数を表す。表 3 に 5 試行中のあ る 1 試行に打ける実験結果を示す。表からは，A4，A5 領 域の線幅変動が設計パターンの $3 \%$ 以内に補正されている ことがわかる。さらに，A4，A5 以外の領域では誤差の值 が殆ど変化していないことから，一部の Adjustable 図形 の調整によって発生する OPE は極めて小さく，他の領域 では無視できることがわかる。また，図 8 に GA 調整の収 束の様子を示す。これより，本論文で提案した，GAによ る Adjustable 図形の調整が有効であることがわかる。

以上の結果より, Adjustable 領域をセルの端から 1.62 $\lambda / N A$ と定義した Adjustable OPCed cell を用いれば，一 部の領域の Adjustable 図形を調整するだけで OPEの高精 度な補正が可能であることがわかる。

$\langle 4 \cdot 3\rangle$ 実 験 2 レイアウト後に回路の一部を修正し た場合，従来の $\mathrm{OPC}$ では再度チップ全面計算が必要であっ 
表 2 レイアウト後の線幅変動（pattern A)

Table 2. Rate of change in intensity contour profile of pattern $\mathrm{A}(\%)$.

\begin{tabular}{c|c|c|c|c|c|c|c|c|c|c|c|c|c}
\hline & A1 & A2 & A3 & A4 & A5 & A6 & A7 & A8 & F1 & F2 & F3 & F4 & total \\
\hline \hline min & 0.13 & 0.05 & 1.44 & 0.95 & 0.02 & 1.12 & 0.07 & 0.06 & 0.18 & 1.51 & 0.71 & 0.30 & 0.02 \\
\hline max & 2.33 & 2.91 & 1.64 & 8.40 & 5.38 & 1.68 & 2.17 & 2.16 & 1.75 & 2.60 & 2.75 & 2.15 & 8.40 \\
\hline average & 0.73 & 1.53 & 1.54 & 3.27 & 2.50 & 1.40 & 0.90 & 1.16 & 0.96 & 2.15 & 2.02 & 1.45 & 1.92 \\
\hline
\end{tabular}

表 3 調整後の線幅変動（pattern A)

Table 3. Rate of change in intensity contour profile of pattern $\mathrm{A}(\%)$.

\begin{tabular}{c|c|c|c|c|c|c|c|c|c|c|c|c|c}
\hline & A1 & A2 & A3 & A4 & A5 & A6 & A7 & A8 & F1 & F2 & F3 & F4 & total \\
\hline \hline min & 0.12 & 0.05 & 1.44 & 0.34 & 0.01 & 1.36 & 0.07 & 0.06 & 0.19 & 1.51 & 0.75 & 0.30 & 0.01 \\
\hline max & 2.33 & 2.91 & 1.64 & 2.29 & 1.99 & 1.66 & 2.17 & 2.16 & 1.75 & 2.61 & 2.76 & 2.15 & 2.91 \\
\hline average & 0.73 & 1.53 & 1.54 & 1.18 & 1.05 & 1.51 & 0.90 & 1.16 & 0.96 & 2.15 & 2.03 & 1.45 & 1.17 \\
\hline
\end{tabular}

表 4 セル変更後の線幅変動（pattern B )

Table 4. Rate of change in intensity contour profile of pattern $\mathrm{B}(\%)$.

\begin{tabular}{c|c|c|c|c|c|c|c|c|c|c|c|c|c}
\hline & A1 & A2 & A3 & A4 & A5 & A6 & A7 & A8 & F1 & F2 & F3 & F4 & total \\
\hline \hline $\min$ & 0.06 & 0.28 & 0.87 & 0.18 & 0.30 & 1.35 & 0.05 & 0.15 & 0.20 & 0.36 & 0.71 & 0.29 & 0.05 \\
\hline $\max$ & 2.37 & 2.56 & 1.77 & 2.52 & 12.33 & 1.61 & 1.30 & 2.18 & 1.71 & 2.74 & 2.67 & 2.17 & 12.33 \\
\hline average & 0.73 & 1.26 & 1.32 & 1.64 & 2.13 & 1.48 & 0.93 & 1.16 & 0.96 & 1.45 & 1.99 & 1.45 & 1.44 \\
\hline
\end{tabular}

表 5 調整後の線幅変動（pattern B)

Table 5. Rate of change in intensity contour profile of pattern $\mathrm{B}(\%)$.

\begin{tabular}{c|c|c|c|c|c|c|c|c|c|c|c|c|c}
\hline & A1 & A2 & A3 & A4 & A5 & A6 & A7 & A8 & F1 & F2 & F3 & F4 & total \\
\hline \hline $\min$ & 0.07 & 0.28 & 0.87 & 0.19 & 0.27 & 1.35 & 0.06 & 0.15 & 0.20 & 0.37 & 0.71 & 0.29 & 0.06 \\
\hline max & 2.37 & 2.56 & 1.77 & 2.52 & 2.61 & 1.61 & 1.30 & 2.18 & 1.71 & 2.73 & 2.67 & 2.17 & 2.73 \\
\hline average & 0.73 & 1.26 & 1.32 & 1.64 & 1.21 & 1.48 & 0.93 & 1.16 & 0.96 & 1.45 & 1.99 & 1.45 & 1.26 \\
\hline
\end{tabular}

た。本実験では，提案手法により，レイアウト後に回路の 一部を修正しても局所的な計算で OPE の補正が可能であ るかを検証する。以下，提案手法を用いた，レイアウト後に 回路修正を行った場合の OPE の補正実験について述べる。

レイアウト後の回路修正として, 実験 1 で調整済みの pattern A 内の cell 4 を, 図 9 (pattern B) の cell 5 に変 更した。なお， pattern B の評価点は 109 箇所設定した。 表 4 に，セルを変更したことにより発生した線幅変動の測 定結果を示す。これより, 回路修正で発生する OPEの影 響は，A5 領域内では大きいが，その他の領域ではほぼ無 視できることがわかる。

そこで, A5 領域内の線幅変動を提案手法により補正し た。目標とする精度は設計パターンの $3 \%$ 以内（適応度 0.33 以上), 染色体の長さは $22, \mathrm{GA} の$ 初期個体は 44 個, 突然 変異の $\sigma$ は $3.0(\mathrm{~nm})$ として調整を行った。表 5 に, 調整 後の pattern Bに扔ける線幅変動の測定結果を示す。この 結果より, 調整前に生じていた最大 $12.33 \%$ の線幅変動が $3 \%$ 以内に抑制されていることがわかる。さらに，A5 領域 の調整がその他の領域には影響を与えていないことも確認 できる。

したがって，本手法を用いることで，レイアウト後に回 路の一部に修正があっても局所的な補正で OPC が実行で きることがわかる。

\section{5. おわりに}

本論文では, OPC 図形の調整が可能な Adjustable 領 域と, OPC 計算が不要な Fixed 領域を持つ Adjustable OPCed cell を考案し，これを用いてレイアウトを行った後 に, Adjustable 領域の OPC 図形を最適化することで OPE を補正する $\mathrm{OPC}$ 手法を提案した。そして, 提案手法を用 いたシミュレーション実験の結果から，本手法を用いるこ とで，レイアウトによって発生する OPE を高精度に補正 できることを示した。さらに，レイアウト後に回路の一部 を修正しても，局所的な補正で OPC が実行できることを 示した。

今後の課題としては, $\mathrm{OPC}$ の計算領域の削減と, $\mathrm{OPC}$ 図形の調整時間の短縮を図ることで, OPC の計算負荷を より低減させる事が考えられる。そのためには, 次の $2 つ$ が課題となる。1つ目は, Fixed 領域を拡大することで計 算領域をより削減させる手法を検討することである。これ は, 使用頻度が多く, 且つ隣接する確率の高いセル同士を 組み合わせて 1 つのセルを定義する等の手法により実現可 能と考えられる。2 つ目は, GA 以外の最適化アルゴリズ ムを用いた OPC 図形の調整手法を検討して比較実験を行 うことにより，レイアウト設計後の OPC 四形の調整によ り適した最適化手法を検討することである。 


\section{謝 辞}

本研究はNEDO から委託されて実施した。また，本研 究を進めるに当たり, STARCよりパターンデータの提供 をいただいた。ここに記して謝意を表する。さらに，貴重 なご意見と有益なご議論をいただいた Seleteの遠藤伸裕氏 ならびに日頃ご指導頂いている産業技術総合研究所次世代 半導体研究センターの廣瀬全孝センター長に感謝する。

(平成 18 年 4 月 19 日受付)

1) M.D. Levenson, N.S. Viswanathan, and R.A. Sympson: "Improving resolution in photolithography with a phase-shifting mask", IEEE,Trans.ElectronDevices, ED-29, pp.18281836 (1982)

(2) M. Noguchi, M. Murai, Y. Iwasaki, and A. Suzuki: "Subhalf micron lithography system with phase shifting effect", in Microlithography, Proc. SPIE symp., Vol.1674, pp.92-104 (1992)

(3) R. Weeks, Jr.: RESOLUTION ENHANCEMENT TECHNIQUES IN OPTICAL LITHOGRAPHY, SPIE PRESS (2001)

(4) P. Gupta, F.-L. Heng, and M. Lavin: "Merits of cellwise model-based opc", Proc. SPIE, Vol.5379, pp.182-189 (2004)

(5) T. Matsunawa, H. Nosato, H. Sakanashi, M. Murakawa, N. Murata, T. Terasawa, T. Tanaka, N. Yoshioka, O. Suga, and T. Higuchi: "The novel approach for optical proximity correction using genetic algorithms", Proc. SPIE, Vol.5992, pp.541549 (2005)

(6) D.E. Goldberg: "Genetic Algorithms in Search, Optimization, and Machine Learning", Addison Wsley Publishing Company Inc.(1989)

(7) O.W. Otto, J.G. Garofali, K.K. Low, C.M. Yuan, R.C. Henderson, C. Pierrat, R.L. Kostelak, S. Vaidya, and P.K. Vasudev: "Automated optical proximity correction - a rulesbased approach", Proc. SPIE, Vol.2197, pp.278-293 (1994)

(8) S. Miyama, L. Yamamoto, and K. Koyama: "Large-area optical proximity correction with a combination of rule-based and simulation-based methods", Jpn.J.Appl.Phys., Vol.35, pp.6370-6373 (1996)

(9) X. Wang, M. Pilloff, H. Tang, and C. Wu: "Exploiting hierarchical structure to enhance cell-based ret with localized opc reconfiguration", Proc. SPIE, Vol.5756, pp.361-367 (2005)

（10）久保田広：「波動光学」，岩波書店 (1979)

(11) H. Satoh, M. Yamamura, and S. Kobayashi: "Minimal generation gap model for gas considering both exploration and exploition", Proc. 4th International Conference on Soft Computing, pp.494-497 (1997)

(12) H.P. Schwefel: Evolution and Optimum Seeking, John Wiley \& Sons(1995)

(13) Semiconductor Industry Association: International Technology Roadmap for Semiconductors, Sematech Inc.(2005)

松 縄 哲 明 (学生員) 1980 年生。2005 年 東海大学大学院工 学研究科光工学専攻博士前期課程修了。同年筑波 大学大学院システム情報工学研究科博士後期課程 入学。現在に至る。進化型光学システム, 適応型 光近接効果補正技術に関する研究に従事。

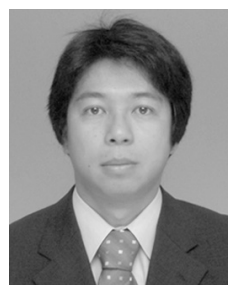

(非会員) 1975 年生。2003 年 東邦大学大学院理 学研究科情報科学専攻博士課程修了。同年日本学 術振興会特別研究員（産業技術総合研究所学振特 別研究員)。2006 年 産業技術総合研究所産総研特 別研究員。現在に至る。遺伝的アルゴリズム，進 化型光学システム, 適応型光近接効果補正技術に 関する研究に従事。博士 (理学)。

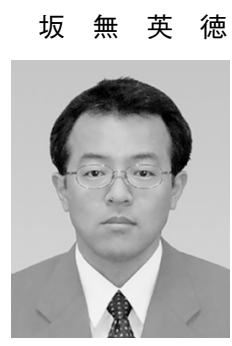

(非会員) 1996 年 北海道大学大学院工学研究科 情報工学専攻博士後期課程修了。1996 年 1998 年 日本学術振興会特別研究員。1998 年 電子技術 総合研究所（現 産業技術総合研究所）入所。進化 的計算理論および進化型ハードウェア，データ圧 縮，半導体の製造時調整技術，救急医療ならびに 電動車いす遠隔支援システム開発などに関する研 究に従事。博士 (工学)。

村 川 正 宏 (正員) 1972 年生。1999 年 東京大学大学院工学

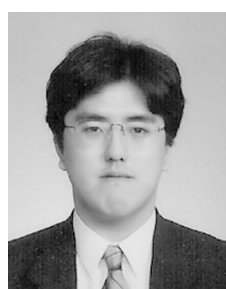
系研究科博士課程修了。工学博士。同年電子技術 総合研究所（現産業技術総合研究所）入所。東邦 大学連携大学院助教授兼任。遺伝的アルゴリズム, 進化型ハードウェア，強化学習の研究に従事。電 気学会会員。第 2 回進化システム国際会議最優秀 論文賞, 平成 12 年度つくば奨励賞, 電気学会ミ レニアム最優秀論文賞受賞。

村 田 信 治 (非会員) 1980 年生。2005 年 東邦大学大学院理 学研究科博士前期課程修了。現在同研究科情報科 学専攻博士後期課程在学中。産業技術総合研究所 非常勤職員として勤務。遺伝的アルゴリズム，多 目的最適化に関する研究に従事。

寺 澤 恒 男 (非会員) 1953 年生。1979 年 東北大学大学院工

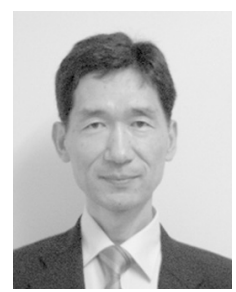
学研究科機械工学専攻修士課程修了。同年 (株) 日 立製作所入社。同社中央研究所にて, 主として光リ ソグラフィ技術の研究開発に従事。2001 年 8 月に 技術研究組合 超先端電子技術開発機構 (ASET) に出向。2006 年 4 月より (株) 半導体先端テク ノロジーズ (Selete) に出向。EUVL マスク関連 技術の研究開発に従事。博士 (工学)。 
田 中 稔 彦 (正員) 1956 年生。1981 年 東京農工大学院工学 研究科修了。同年 (株) 日立製作所入社。同社中 央研究所にて光リソグラフィの研究開発に従事。 $\mathrm{i}$ 線リソグラフィ, 位相シフト露光技術, 化学増 幅系レジストプロセス等の開発を手がける。1990 年から 92 年にかけ, (株) ソルテック筑波研究所 にてX 線リソグラフィの開発に従事。2003 年に (株) ルネサステクノロジに籍を移し，2004 年か ら 06 年 3 月まで半導体 MIRAI プロジェクトにてリソグラフィ関連 計測技術を開発。現在, (株) 半導体先端テクノロジーズにて EUVリ ソグラフィ技術開発に従事。グループリーダー。博士（工学）。
須 賀

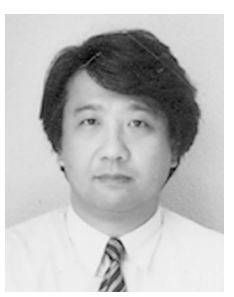

治（非会員） 1954 年生。1980 年 東京都立大学大学 院機械工学研究科卒。同年（株）日立製作所中央 研究所入社。主として電子ビームリソグラフイ技 術の研究・開発に従事。その後, エルピーダメモ リ (株), (株) 先端 $\mathrm{SoC}$ 基盤技術開発などでの光 リソグラフィおよび光マスクの技術開発を経て現 在, (株) 半導体先端テクノロジーズの EUVL マ スク開発に従事。プログラムマネージャ。

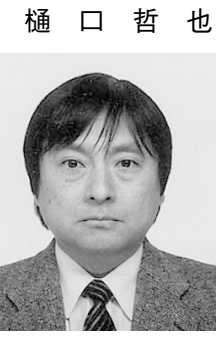

(非会員) 1982 年 慶応大学大学院工学研究科博 士課程終了。工学博士。1983 年 電子技術総合研 究所入所。1990 年 1991 年 カーネギーメロン 大客員研究員。現在, 産業技術総合研究所次世代 半導体研究センター主幹研究員。筑波大学連携大 学院教授兼任。進化型ハードウェア, 遺伝的アル ゴリズムの研究に従事。第 25 回市村学術賞, 電 気学会ミレニアム最優秀論文賞等受賞。電子情報

通信学会会員。 